\title{
Mutual fund performance: dividends do matter
}

\author{
Diego Víctor de Mingo-López \\ Juan Carlos Matallín-Sáez ${ }^{1}$
}

\begin{abstract}
This paper studies the bias in mutual fund performance when a non-dividendreinvesting benchmark is used. Our empirical findings show how performance worsens when using a benchmark that includes reinvestment dividends. We also find that inferences about managers' ability related to economic states are biased by the effect of omitting dividends when selecting a benchmark.
\end{abstract}

Keywords: Mutual funds, performance, dividends, benchmark.

JEL code: G12

\footnotetext{
${ }^{1}$ This study is part of the research projects P11B2012-07 supported by the Universitat Jaume I and ECO2011-27227 supported by the Spanish Ministerio de Ciencia e Innovación. Address for correspondence: Juan C. Matallín-Sáez, Department of Finance and Accounting, Universitat Jaume I, E-12080 Castellón, Spain. Tel: +34 964728 560, Fax: +34964728 565. E-mail: matallin@uji.es.
} 


\section{Introduction}

The significant development of mutual funds during recent decades has motivated interest about this topic in the financial literature. In reviews by Ferson (2010) and Elton and Gruber (2011) of the topics related to mutual funds analysed by researchers, mutual fund performance emerged as one that has captured most academic attention. Based on the studies by Treynor (1965), Sharpe (1966) and Jensen (1968), many authors have proposed different models to measure performance. Nowadays, multi-factor models, as in Fama and French (1993) and Carhart (1997), are commonly used. In these models, the stock market excess return is the main factor to explain equity mutual fund returns.

In this context, Lehmann and Modest (1987) demonstrate that the benchmark decision can affect performance results. Sainz et al. (2006) affirm that this choice is one of the main questions in evaluating the management of fund managers. Matallín (2006) demonstrates the bias caused when benchmarks are omitted that represent asset categories in which mutual funds invest. In this line, our objective is to analyse the effect on mutual fund performance of choosing a nondividend-reinvesting or a dividend-reinvesting stock market benchmark. Typically the most popular stock market indexes do not incorporate dividend reinvestment return, but mutual funds do obtain dividends and they incorporate them in their portfolios. Despite this critical difference between mutual funds and typical benchmarks, we find no previous studies addressing this issue. We contribute to the literature by showing the importance of the bias arising by omitting reinvestment of dividends in mutual fund performance. Our hypothesis is that mutual fund performance increases when a non-dividend-reinvesting benchmark is chosen, and this effect is more relevant in a period of economic crisis if return from dividends is higher. However this is a bias in the measurement of mutual fund performance, and creates the false impression that fund managers are able to manage better in crisis periods.

For a sample of Spanish mutual funds, we observe, in general terms, that mutual funds cannot beat a benchmark which reinvests dividends, but they do beat a benchmark without return dividend. Moreover this difference is higher in a period of economic crisis, which confirms our initial hypothesis. In view of this evidence, the present paper contributes by warning investigators and analysts about the importance of choosing a dividend-reinvesting market factor as a benchmark in the mutual fund performance measurement if they hope to explain mutual fund management accurately.

The next section describes the sample used. Section 3 explains the methodology. Section 4 reports the results of our analysis. Finally, the main conclusions are exposed.

\section{Data}

The analysis period runs from December 1999 to January 2014. One of our hypotheses is that performance increase is caused by using a market factor which does not reinvest dividends; this increase is higher in a period of economic crisis. Therefore, we also differentiate a pre-crisis period (first sub-period) from a crisis period (second sub-period), and we observe the differences in the performance of mutual funds when it is compared with the returns obtained by the benchmarks considered during these two periods. Based on the historical evolution of the Spanish stock market index IBEX35, we consider the period from December 1999 to December 
2007 as the first sub-period, and the period from January 2008 to January 2014, as the second sub-period.

A sample of 108 Spanish equity mutual funds is used in the empirical analysis. The sample excludes equity mutual funds whose issuers are not Spanish, and those who have fewer than 30 data for running regressions, to ensure the robustness of our empirical analysis. Monthly returns were provided by the Morningstar database. Some descriptive statistics of mutual fund returns are shown in Panel A of Table 1. For each fund, return and risk (s.d.) are calculated, both for the full sample and for the two sub-periods. These values were used to calculate the mean, median and percentiles. The table shows that funds have a lower performance and a higher risk in the second period.

We used the following stock market indexes as market factors: the IBEX 35 index, which is a value-weighted index with the 35 most traded stocks and is commonly used as a benchmark for Spanish equity mutual funds; and the IBEX35 TR (total return) index, which is a similar index as the IBEX35 but reinvesting the generated dividends. The monthly price data for these indexes were provided by the Morningstar database. As the risk-free rate we use monthly return from 1-day T-bill repos index provided by Analistas Financieros Internacionales (AFI).

We also need data on the SMB and HML factors to estimate the Fama-French three-factor model. SMB represents the size-factor, and is calculated as the return difference between small and large capitalization stocks. HML represents the book-to-market factor, and is calculated as the return difference between value stocks (stocks with a high book-to-market ratio) and growth stocks (stocks with a low book-to-market ratio). To calculate these factors, we follow the methodology described in Andreu and Sarto (2013) and use data from Morningstar.

Some descriptive statistics of the market factors, SMB and HML are presented in Panel B of Table 1. Although the risks of IBEX35 and IBEX35 TR are very similar, the return of the latter is higher than that of the former; specifically, the difference is $4.02 \%$ for the whole period sample, $2.67 \%$ for the first sub-period and $5.80 \%$ for the second sub-period. As indicated above, during the crisis period the dividend reinvestment return tends to increase, as in the second subperiod of our sample. A comparison of panels A and B of Table 1 reveals that the aggregated mean of mutual fund returns is higher than the mean of the IBEX35 in the period and subperiods considered, but lower for the case of IBEX35 TR, except in the first sub-period. These data show at first glance how using a benchmark without return dividend funds improves the results.

\section{Methodology}

We analyse the differences in mutual fund performance according to the benchmark considered. In particular, we explore the differences using a market factor that either reinvests dividends or does not. As in Andreu and Sarto (2013), we apply two asset pricing models widely used in the mutual fund performance literature: in the CAPM model shown in expression (1) performance is measured according to Jensen (1968), and in (2) it is measured using an alpha extended version under the three-factor model of Fama and French (1993).

$$
r_{p, t}=\alpha_{p}+\beta_{p, m} r_{m, t}+\varepsilon_{p, t}
$$




$$
r_{p, t}=\alpha_{p}+\beta_{p, m} r_{m, t}+\beta_{p, S M B} S M B_{t}+\beta_{p, H M L} H M L_{t}+\varepsilon_{p, t}
$$

where $r_{p, t}$ is the excess risk-free return on the mutual fund $p$ in month $t, r_{m, t}$ is the excess riskfree return on a market portfolio in month $t$, alternatively IBEX35 or IBEX35 TR, and $S M B_{t}$ and $H M L_{t}$ are returns on zero-investment, mimicking portfolios for the common size and for the common book-to-market ratio in month $t$, respectively.

\section{Results}

Mutual fund performance results from the whole period sample, from December 1999 to January 2014, using models described in expressions (1) and (2), are shown in Panel A of Table 2 .

According to the models, aggregated mutual fund performance is positive when the IBEX35 is used as the market factor, but negative when a dividend-reinvesting index (IBEX35 TR) is selected. Moreover, more than a half of the funds beat the first market index in a statistically significant way, while few do so when dividends in the market index are considered. The difference in the annual performance when choosing one or the other benchmark, $3.83 \%$ according to the CAPM, and $3.96 \%$ according to the Fama and French model, is statistically significant.

Consequently, we can affirm that the IBEX35, because it does not reinvest the dividends generated, has lower returns, making it easier to beat. From this we interpret that funds' performance measure value can be distorted if an appropriate market factor is not used. This result is consistent with our hypothesis that erroneous conclusions are reached when using a market factor that does not reinvest dividends.

Panel B of Table 2 shows the performance estimated for the first sub-period, December 1999 December 2007, (pre-crisis sub-period), while Panel C analyzes the second sub-period, January 2008 - January 2014, (crisis sub-period). We note that the mean annual performance in both sub-periods is positive using the IBEX35, but negative using the benchmark that reinvests dividends, again creating statistically significant differences in performance when using one or the other. While these differences are 2.36\% (according to CAPM) and 2.39\% (according to the three-factor model) in the first sub-period, we can see that these differences increase in the following sub-period to 5.29\% and 5.49\% (according to the CAPM and the Fama-French models, respectively), and more funds are able to outperform the IBEX35. Furthermore, no fund is beaten by the IBEX35 in a statistically significant way during the second sub-period.

In view of the results of Panel B and Panel C, we can observe that the difference between the mutual fund performance using a market factor with or without dividend reinvestment is more relevant in the second sample sub-period. For this reason, we suspect that the increase in the differences is caused by a change in the effect of dividends. To verify this change, we run the following regression:

$$
\text { ibextr }_{t}=a+b \cdot \text { ibex }_{t}+\varepsilon_{t}
$$

where $i b e x t r_{t}$ and $i b e x_{t}$ are the excess risk-free returns on the IBEX35 TR and on the IBEX35 in month $t$, respectively. 
Table 3 shows the results of estimating (3) for both sub-periods. In the first sub-period, the IBEX35 TR's alpha (a) takes an annualized value of $2.66 \%$, this value being due to the return linked to dividends. In the second sub-period, the IBEX35 TR also outperforms the IBEX35 with an annualized alpha of $5.78 \%$, which implies that the effect of dividends has increased. In fact, these values are very similar to the differences using a non-dividend-reinvesting or a dividend-reinvesting market factor in both sub-periods (comparing the average of mutual fund performance in panels $\mathrm{B}$ and $\mathrm{C}$ of Table 2). These results are consistent with our hypothesis that, in times of crisis, using a market factor which does not reinvest dividends causes a higher bias in the analysis of the performance of mutual funds.

Because of the importance of the dividend effect, we test whether significant differences exist in the mutual fund performance between the first and second sub-periods, using the same market factor in both sub-periods. Table 4 shows the results of analyzing timing differences between the two sub-periods.

We can see that there are statistically significant differences between the means of the alphas of the two sub-periods using the IBEX35 as the market factor, according to both asset pricing models. This means that when using a market factor that does not include dividends, funds perform better in the second sub-period, a crisis period. Thus, using a market factor without dividends leads us to the biased conclusion that managers perform better in a state of crisis than in a growing state.

However, if we consider the IBEX35 TR, the opposite results are found. According to the CAPM, fund managers manage less badly in the first sub-period, and according to the FamaFrench model this is not significant. Considering that this last model is more complete for evaluating performance, the final result will be that funds perform similarly in both sub-periods when using a dividend-reinvesting benchmark.

\section{Conclusions}

Mutual fund performance can be calculated using asset pricing models, such as the CAPM and the Fama-French three-factor model. One of their explanatory variables is the market factor, or benchmark. Market factor selection is a very important aspect because it affects the mutual fund performance.

In this paper, we expose the differences in mutual fund performance generated by choosing a non-dividend-reinvesting or a dividend-reinvesting benchmark. If we select a non-dividendreinvesting index (e.g., IBEX35), mutual fund performance will be overvalued; results will show erroneous conclusions, and it will seem that fund managers perform better than they really do. Moreover, if the return by dividend changes, we will have erroneous evidence about the times when fund managers are able to provide a higher added value to their portfolios. The biased results using the IBEX35 will indicate that managers perform better in crisis times, but in reality, with the IBEX35 TR, this conclusion is the opposite or even non-existent, according to the performance model we ran.

Therefore, the right model for mutual fund performance analysis is one with a dividendreinvesting benchmark, because mutual funds also reinvest the generated dividends. Otherwise, results will be distorted. 


\section{References}

Andreu, L. and Sarto, J. L. (2013) Financial consequences of mutual fund mergers, The European Journal of Finance, (ahead-of-print), 1-22.

Carhart, M. M. (1997) On persistence in mutual fund performance, The Journal of Finance, 52, 57-82.

Elton, E. J. and Gruber, M. J. (2011) Mutual funds, Financial Markets and Asset.

Fama, E. and French, K. (1993) Common risk factors in the returns on stocks and bonds, Journal of Financial Economics, 33, 3-56.

Ferson, W. E. (2010) Investment Performance Evaluation, Annual Review of Financial Economics, 2 , 207-324.

Jensen, M. (1968) The performance of mutual funds in the period 1945-1964, Journal of Finance, 23, 389-415.

Lehmann, B. N. and Modest, D. M. (1987) Mutual Fund Performance Evaluation: A Comparison of Benchmarks and Benchmark Comparisons, The Journal of Finance, 42, 233-65.

Matallín-Sáez, J. C. (2006) Seasonality, market timing and performance amongst benchmarks and mutual fund evaluation, Journal of Business Finance and Accounting, 33, 1484-507.

Sainz, J., Grau, P. and Doncel, L. M. (2006) Mutual fund performance and benchmark choice: the Spanish case, Applied Financial Economics Letters, 2, 317-21.

Sharpe, W. (1966) Mutual fund performance, Journal of Business, 39, 119-38.

Treynor, J. L. (1965) How to rate management of investment funds, Harvard Business Review, 43, 63-75. 


\section{Tables}

Table 1: Descriptive statistics of the sample

\section{Panel A}

\begin{tabular}{|c|c|c|c|c|c|c|}
\hline \multirow[b]{2}{*}{ Mutual fund returns } & \multicolumn{2}{|c|}{1999 December - 2014 January } & \multicolumn{2}{|c|}{1999 December - 2007 December } & \multicolumn{2}{|c|}{2008 January - 2014 January } \\
\hline & Return & Risk & Return & Risk & Return & Risk \\
\hline Mean & $2.26 \%$ & $19.81 \%$ & $6.94 \%$ & $15.58 \%$ & $-2.42 \%$ & $22.98 \%$ \\
\hline Median & $4.62 \%$ & $19.89 \%$ & $7.79 \%$ & $16.55 \%$ & $-1.58 \%$ & $22.85 \%$ \\
\hline $10^{\text {th }}$ Percentile & $-1.50 \%$ & $16.42 \%$ & $2.05 \%$ & $11.03 \%$ & $-8.53 \%$ & $19.53 \%$ \\
\hline $90^{\text {th }}$ Percentile & $7.21 \%$ & $21.51 \%$ & $17.07 \%$ & $19.02 \%$ & $1.63 \%$ & $25.76 \%$ \\
\hline
\end{tabular}

Panel B

\begin{tabular}{|c|c|c|c|c|c|c|}
\hline \multirow[b]{2}{*}{ Factors returns } & \multicolumn{2}{|c|}{1999 December - 2014 January } & \multicolumn{2}{|c|}{1999 December - 2007 December } & \multicolumn{2}{|c|}{2008 January - 2014 January } \\
\hline & Mean return & Risk & Mean return & Risk & Mean return & Risk \\
\hline IBEX35 & $-0.63 \%$ & $21.25 \%$ & $2.73 \%$ & $18.88 \%$ & $-5.09 \%$ & $24.11 \%$ \\
\hline IBEX35 TR & $3.39 \%$ & $21.25 \%$ & $5.40 \%$ & $18.98 \%$ & $0.71 \%$ & $24.05 \%$ \\
\hline SMB & $1.67 \%$ & $17.08 \%$ & $4.14 \%$ & $18.64 \%$ & $-1.60 \%$ & $14.82 \%$ \\
\hline HML & $1.99 \%$ & $16.84 \%$ & $7.82 \%$ & $13.04 \%$ & $-5.75 \%$ & $20.75 \%$ \\
\hline
\end{tabular}


Table 2: Mutual fund performance

Panel A. Whole period sample: 1999 December - 2014 January

\begin{tabular}{|c|c|c|c|c|c|c|}
\hline & $\begin{array}{l}\text { Annualized mean } \\
\text { performance }\end{array}$ & $\begin{array}{l}\text { Number } \\
\text { of funds }\end{array}$ & $\begin{array}{l}\text { Percentage of } \\
\text { funds with } \alpha_{p}<0\end{array}$ & $\begin{array}{l}\text { Percentage of } \\
\text { funds with } \alpha_{p}>0\end{array}$ & $\begin{array}{l}\text { Percentage of funds with } \\
\alpha_{p}<0, p \text { value }<0.05\end{array}$ & $\begin{array}{l}\text { Percentage of funds with } \\
\alpha_{p}>0, p \text { value }<0.05\end{array}$ \\
\hline (1) CAPM, $r_{m, t}$ without dividends & $2.55 \%$ & 108 & $12.04 \%$ & $87.96 \%$ & $1.85 \%$ & $55.56 \%$ \\
\hline (2) CAPM, $r_{m, t}$ with dividends & $-1.28 \%$ & 108 & $78.70 \%$ & $21.30 \%$ & $43.52 \%$ & $0.93 \%$ \\
\hline (3) Difference: (1) - (2) & $3.83 \%$ & & & & & \\
\hline$p$-value & $(0.000)$ & & & & & \\
\hline (4) $F F, r_{m, t}$ without dividends & $2.51 \%$ & 108 & $12.04 \%$ & $87.96 \%$ & $1.85 \%$ & $57.41 \%$ \\
\hline (5) $F F, r_{m, t}$ with dividends & $-1.45 \%$ & 108 & $83.33 \%$ & $16.67 \%$ & $43.52 \%$ & $2.78 \%$ \\
\hline (6) Difference: (4) - (5) & $3.95 \%$ & & & & & \\
\hline$p$-value & $(0.000)$ & & & & & \\
\hline
\end{tabular}

Panel B. Pre-crisis period: 1999 December - 2007 December

\begin{tabular}{|c|c|c|c|c|c|c|}
\hline & $\begin{array}{l}\text { Annualized mean } \\
\text { performance }\end{array}$ & $\begin{array}{l}\text { Number } \\
\text { of funds }\end{array}$ & $\begin{array}{l}\text { Percentage of } \\
\text { funds with } \alpha_{p}<0\end{array}$ & $\begin{array}{l}\text { Percentage of } \\
\text { funds with } \alpha_{p}>0\end{array}$ & $\begin{array}{l}\text { Percentage of funds with } \\
\alpha_{p}<0, p \text { value }<0.05\end{array}$ & $\begin{array}{l}\text { Percentage of funds with } \\
\alpha_{p}>0, p \text { value }<0.05\end{array}$ \\
\hline (1) CAPM, $r_{m, t}$ without dividends & $1.86 \%$ & 95 & $18.95 \%$ & $81.05 \%$ & $3.16 \%$ & $31.58 \%$ \\
\hline (2) CAPM, $r_{m, t}$ with dividends & $-0.49 \%$ & 95 & $74.74 \%$ & $25.26 \%$ & $34.74 \%$ & $10.53 \%$ \\
\hline (3) Difference: (1) - (2) & $2.35 \%$ & & & & & \\
\hline $\mathrm{p}$-value & $(0.000)$ & & & & & \\
\hline (4) $F F, r_{m, t}$ without dividends & $1.52 \%$ & 95 & $21.05 \%$ & $78.95 \%$ & $3.16 \%$ & $30.53 \%$ \\
\hline (5) $\mathrm{FF}, \mathrm{r}_{\mathrm{m}, \mathrm{t}}$ with dividends & $-0.87 \%$ & 95 & $77.89 \%$ & $22.11 \%$ & $41.05 \%$ & $8.42 \%$ \\
\hline (6) Difference: (4) - (5) & $2.39 \%$ & & & & & \\
\hline $\mathrm{p}$-value & $(0.000)$ & & & & & \\
\hline
\end{tabular}


Panel C. Crisis period: 2008 January - 2014 January

\begin{tabular}{|c|c|c|c|c|c|c|}
\hline & $\begin{array}{l}\text { Annualized mean } \\
\text { performance }\end{array}$ & $\begin{array}{l}\text { Number } \\
\text { of funds }\end{array}$ & $\begin{array}{l}\text { Percentage of } \\
\text { funds with } \alpha_{p}<0\end{array}$ & $\begin{array}{l}\text { Percentage of } \\
\text { funds with } \alpha_{p}>0\end{array}$ & $\begin{array}{l}\text { Percentage of funds with } \\
\alpha_{p}<0, p \text { value }<0.05\end{array}$ & $\begin{array}{l}\text { Percentage of funds with } \\
\alpha_{p}>0, p \text { value }<0.05\end{array}$ \\
\hline (1) CAPM, $r_{m, t}$ without dividends & $3.64 \%$ & 104 & $5.77 \%$ & $94.23 \%$ & $0.00 \%$ & $59.62 \%$ \\
\hline (2) CAPM, $r_{m, t}$ with dividends & $-1.65 \%$ & 104 & $83.65 \%$ & $16.35 \%$ & $34.62 \%$ & $0.00 \%$ \\
\hline (3) Difference: (1) - (2) & $5.29 \%$ & & & & & \\
\hline $\mathrm{p}$-value & $(0.000)$ & & & & & \\
\hline (4) $F F, r_{m, t}$ without dividends & $4.07 \%$ & 104 & $4.81 \%$ & $95.19 \%$ & $0.00 \%$ & $72.12 \%$ \\
\hline (5) $\mathrm{FF}, \mathrm{r}_{\mathrm{m}, \mathrm{t}}$ with dividends & $-1.41 \%$ & 104 & $78.85 \%$ & $21.15 \%$ & $38.46 \%$ & $1.92 \%$ \\
\hline (6) Difference: (4) - (5) & $5.49 \%$ & & & & & \\
\hline$p$-value & $(0.000)$ & & & & & \\
\hline
\end{tabular}


Table 3: Results of equation (3), estimating a linear relationship between the benchmark with dividends and without dividends

\begin{tabular}{llllll}
\hline Dependent Variable & \multicolumn{2}{c}{ December 1999- December 2007 } & & \multicolumn{2}{c}{ January 2008 - January 2014 } \\
\cline { 2 - 3 } \cline { 5 - 6 } Excess return of IBEX35 TR & Coefficient & P-value & & Coefficient & P-value \\
\hline$a$ & $2.64 \%$ & $(0.0000)$ & & $5.76 \%$ & $(0.0000)$ \\
$b$ & 1.0046 & $(0.0000)$ & & 0.9953 & $(0.0000)$ \\
R-squared & 0.9981 & & 0.9957 & \\
\hline
\end{tabular}

Table 4: Differences between annualized mean performances of different periods

\begin{tabular}{|c|c|c|c|c|}
\hline & (1) Annualized mean performance 1999-2007 & (2) Annualized mean performance 2008-2014 & (3) Difference, (2) - (1) & p-value \\
\hline CAPM, $r_{m, t}$ without dividends & $1.86 \%$ & $3.64 \%$ & $1.78 \%$ & $(0.000)$ \\
\hline CAPM, $r_{m, t}$ with dividends & $-0.49 \%$ & $-1.65 \%$ & $-1.16 \%$ & $(0.007)$ \\
\hline $\mathrm{FF}, \mathrm{r}_{\mathrm{m}, \mathrm{t}}$ without dividends & $1.52 \%$ & $4.07 \%$ & $2.55 \%$ & $(0.000)$ \\
\hline $\mathrm{FF}, \mathrm{r}_{\mathrm{m}, \mathrm{t}}$ with dividends & $-0.87 \%$ & $-1.41 \%$ & $-0.54 \%$ & $(0.179)$ \\
\hline
\end{tabular}

